\title{
Empathic Communication in Cooperative Play of 2 and 3 Year Olds
}

\author{
Paula Gabrielly Rasia Lira' ${ }^{1}$ (D) https://orcid.org/0000-0003-2077-1948 \\ Maria Isabel Pedrosa ${ }^{1}$ (D) https://orcid.org/0000-0002-7273-8157
}

\begin{abstract}
Although empathy is the key to interpersonal relationships, it has been little investigated in children and partners. Empathy is considered a multidimensional construct with affective, cognitive and social components. The present study aimed to understand the construction of cooperative play through empathy in 2-3 year olds. The empathic phenomenon was inferred through behaviors that denote satisfaction, threat, dispute, reconciliation, comfort, among others, emphasizing its communicative role. Twenty children were videotaped in free interaction in a municipal public day care center. Data were qualitatively analyzed - microgenetic analysis of video recordings - and showed that although empathic communication is constitutive of cooperative coordinated play, it does not guarantee its accomplishment. Imitation is the most used strategy for a child to fit into an already structured play. The study empirically reveals the social dimension of empathy and highlights the relevance of investigating children in interaction with peers.
\end{abstract}

Keywords: empathy, social interaction, intentionality, play development

\section{Comunicação Empática na Brincadeira Cooperativa de Crianças de 2 e 3 Anos}

\begin{abstract}
Resumo: A empatia é fundamental para as relações interpessoais, mas pouco investigada entre crianças e parceiros. É considerada um construto multidimensional com componentes afetivos, cognitivos e sociais. O presente estudo objetivou compreender a construção de brincadeiras cooperativas por meio da empatia em crianças de 2-3 anos. O fenômeno empático foi inferido por meio de comportamentos que denotam satisfação, ameaça, disputa, reconciliação, conforto, entre outros, enfatizando-se seu papel comunicativo. Vinte crianças foram videogravadas em situação de interação livre em uma creche pública municipal. Os dados foram analisados qualitativamente - análise microgenética de videogravações - e evidenciam que apesar de a comunicação empática ser constitutiva de brincadeiras coordenadas cooperativas, ela não assegura a efetivação destas. A imitação é a estratégia mais utilizada para uma criança se inserir em uma brincadeira já estruturada. O estudo revela empiricamente a dimensão social da empatia e realça a pertinência de se investigar crianças em interação com pares de idade.
\end{abstract}

Palavras-chave: empatia, interação social, intencionalidade, desenvolvimento do brincar

\section{Comunicación Empática en el Juego Cooperativo entre Niños de 2 y 3 años}

\begin{abstract}
Resumen: La empatía es esencial en las relaciones interpersonales, pero poco se estudia entre niños y sus pares. Se considera un constructo multidimensional con componentes afectivos, cognitivos y sociales. El presente estudio tuvo como objetivo comprender la construcción de juegos cooperativos mediante la empatía entre niños de 2 a 3 años de edad. Se infirió el fenómeno empático mediante comportamientos que denotan satisfacción, amenaza, disputa, reconciliación, comodidad, entre otros, enfatizando su papel comunicativo. Se grabaron a veinte niños en interacción libre en una guardería pública municipal. Se realizó un análisis de datos cualitativo - análisis microgenético de las imágenes de video -, que apunta que los juegos cooperativos coordinados de los niños se basan en la comunicación empática, pero esta no garantiza su efectividad. La estrategia más utilizada por el niño para insertarse en un juego ya estructurado es la imitación. El estudio evidencia empíricamente la dimensión social de la empatía y destaca la relevancia de investigar la interacción infantil entre pares.
\end{abstract}

Palabras clave: empatía, interacción social, intencionalidad, desarrollo del juego

\footnotetext{
${ }^{1}$ Universidade Federal de Pernambuco, Recife-PE, Brazil

Support: Article derived from the master's dissertation of the first author under the supervision of the second author, presented in 2017 in the Graduate Program in Psychology of the Universidade Federal de Pernambuco.

Correspondence Address: Paula Gabrielly Rasia Lira. Laboratório de Interação Social Humana - Departamento de Psicologia, Uiversidade Federal de Pernambuco. Avenida da Arquitetura, s/n, Dep. de Psicologia, $9^{\circ}$ andar do CFCH, UFPE. CEP: 50740-550. E-mail: paulagrasia@gmail.com
}

The concept of empathy has a long history in the scientific world. The term arose from the German word einfühlung, whose meaning was related to the context of nineteenthcentury theory of aesthetics, referring to a projection of an observer's internal predisposition in response to his perception of an aesthetic object, "to feel in". It was first translated into English by psychologist Edward Tichener, 
who, in 1909, used the term empathy to discuss the ability to know the consciousness and feelings of others through an internal imitation process (Gómez, 2016).

For Plutchik (1990), empathy would constitute a component of affective communication, providing the apprehension of another's emotional state. It would be triggered by behavioral display, which would be highly likely to induce similar feelings and emotions in individuals who perceive such display. Thus, the empathic phenomenon is linked to the use of physiognomic, gestural, postural and rhythmic resources.

Del Prette and Del Prette (2013, p. 150) define empathy as the "ability to understand and feel what someone feels in a situation of affective demand, adequately communicating such understanding and feeling". This definition articulates and integrates cognitive aspects, which involve the adoption process from the point of view of the interlocutor; affective aspects, which refer to the experience of the other's emotion; and behavioral aspects, which concern the ability to express understanding. Other authors also seek to approach the empathic phenomenon as a multidimensional concept that incorporates cognitive, affective and behavioral aspects (Gómez, 2016; Pinho, Falcone, \& Sardinha, 2016).

Empathy is inferred from behaviors; there are displays that are associated with various affective dispositions of those who present them and, therefore, are taken as revealing of the empathic phenomenon. A person who observes another and identifies need, desire, suffering, joy, or any other emotional state may offer an empathic response to it. The latter, in turn, assesses the willingness of the "offering" partner, with likely repercussions for his/ her own behavior (Plutchik, 1990). The empathic response is also called the vicarious response of feelings perceived in the other; "...it refers to any reaction arising from putting oneself in the other's shoes, which includes both similar (imitation) and complementary (e.g. support or sharing) reactions" (Del Prette \& Del Prette, 2013, p. 150).

Research in neuroscience has revealed the possibility of a person mapping the sensations of another through their somatosensory representation. There is a multimodal integration in the brain that activates the motor and somatosensory system itself by perceiving others' tactile experiences and actions (Gallese, 2013; Gallese \& Ebisch, 2013). In an extensive review article, de Waal and Preston (2017) summarized more recent neuroscientific evidence from studies on empathy in humans and other mammals. These authors discuss a set of data that favor the conception of an interconnection at the level of neural mechanisms that support the development of empathy models: the perception-action model (PAM) and the mirror neuron model. According to PAM, "individuals understand and have a perception of another's emotions, because the nervous system has evolved to map others' states into one's own individual representations to experience these states" (p. 499).

The study with children deepens the theme of empathy due to the recognition of this phenomenon in the first years of life. This calls into question the concept of selfdecentralization, or overcoming egocentrism, according to the Piagetian explanation, for the condition of the child putting himself in the perspective of the other around the age of seven (Piaget \& Inhelder, 1966/1980). In contrast, the Wallonian theory emphasizes emotion early in life, whose primary function seems to be to exert an action on the other and to bring about harmony of reaction and impulse with the partner through the sensory-motor system, which supports postural mime, the organic expression of its endogenous dispositions (Wallon, 1949/1986). For this author, emotions have a contagious character that triggers the first communicative system of the human being, assuring him the beginnings of social relations.

Currently, we seek to overcome the dichotomy cognition versus affectivity by recognizing the integrality of the ontogenetic process. It is argued that the affective and cognitive aspects of empathy in child research appear remarkably from the age of eight months and gradually increase over the second year of life (Roth-Hanania, Davidov, \& Zahn-Waxler, 2011). Bischof-Köhler $(2012,2013)$ in his paper on empathy in children in their second year of life discussed the existence of four child response patterns to discomfort or suffering of an adult playmate: offer help, feel perplexed, emotional contagion, indifference. The help pattern shows signs of concern and compassion, trying to help or comfort the playmate through actions such as fixing the broken toy, calling an adult to help, and even shifting the pair's focus of attention.

Costa and Amorim (2015) argue that care, comfort and defense behaviors are also observed in child-child interactions from the first year of life. This ability of children to take care of their peers in the early period of life can be observed in play, as well as in interactional situations when the playful components are less evident. In this second situation, the motivation to interact would not be in play, but in helping the pair. Empathy is imbricated in social interactions, hence situations with partners constitute the privileged field for the investigation of this phenomenon (Bussab, Pedrosa, \& Carvalho, 2007).

Children - who have not yet mastered the socially available language code - interact, and many of their interactions take place through empathic responses. These, therefore, correspond to a means of communication which makes it possible to grasp each other's dispositions to be together, play together, or undertake any collaborative enterprise. For this reason, there is an interest in examining situations of observation of group play, in which children strive for a playful venture with known partners, since playing is recognized as a high priority motivational activity (Menezes \& Bichara, 2016). It is hypothesized that empathic communication in children in the early years plays a role in the construction of their cooperative play, since putting oneself in the other's place implies sensitivity to that other, and continual evaluations of one's affective dispositions, which include the interest in playing and keep playing. As a result, action adjustments are promoted to undertake or persist with the cooperative activity. Cooperative play is characterized by the negotiation and coordination of the enterprise around the same theme. This process would suggest an ability to share intentionality (Tomasello \& Gonzalez-Cabrera, 2017). 
The study of empathy in children is justified by the relevance of observing empathic manifestation at an early age (Bischof-Köhler, 2012, 2013; Bussab et al., 2007; Roth-Hanania et al., 2011), when sophisticated interpretive resources are not available in this early period of life, so that the child can benefit from formal and systematic teaching on how to deal with the other. Hence the interest of neurosciences in this theme (de Waal \& Preston, 2017; Gallese, 2013; Gallese \& Ebisch, 2013). Developmental psychology also considers it relevant to know the ontogenesis of empathy and its relationship with processes of cooperation and altruism (Pessôa, Seidl-de-Moura, Mendes, Carvalho, \& Stobaus, 2015; Wallon, 1949/1986). Considering that empathy is fundamental for interpersonal relationships, studying it through group observation of children can contribute to highlighting its social role in the development of partner relationships. The present study aimed to understand the construction of cooperative play through empathy in 2-3 year olds. Considered a multidimensional construct with affective, cognitive and social components, the empathic phenomenon was inferred through behaviors that denote satisfaction, partner acceptance, threat, dispute, reconciliation, comfort, among others, emphasizing its communicative role in interpersonal relationships.

\section{Method}

Educational institutions are privileged observation spaces for children's studies, especially regarding the interactional dynamics (Saullo, Rossetti-Ferreira, \& Amorim, 2013). So, the present study was carried out in a daycare center that served children under 3 years old, coming from low-income families living in Recife. The daycare center was a public institution and it was invited to integrate the research out of convenience, as it was located on a large avenue, reachable by bus, which facilitated access for the entire research team.

\section{Participants}

Twenty children belonging to the same age group of the daycare center participated in the research. They were on average 31 months old at the beginning of the study, and ages ranged from 25 to 37 months. The age group chosen is justified by the fact that the children are already moving with dexterity and have an incipient language, but offering some verbal clues that helped to capture their affective dispositions. There was a period prior to the actual collection for researchers and children to get acquainted with each other, and also to create a friendly atmosphere with the professional adults of the daycare center.

\section{Instruments}

The observations of the children were video recorded based on using a camera.

\section{Procedure}

Data collection. The observations and recording of the children took place in a free activity situation. The sessions took place in their own reference room they used to attend (group II of the daycare center). There were six observation sessions, with an average duration of 20 minutes, almost weekly. The use of video recording enabled the researcher to better grasp the phenomenon investigated, as it allowed to watch the behavior of children as often as necessary and as it really occurred, in the concrete situation.

Data analysis. A microgenetic analysis of video recordings was carried out. This analysis consists in identifying even subtle transformations that may be revealing of ongoing psychological processes: the situation is meticulously described, as the sequence of behaviors, the chain of actions and the meanings attributed to them are followed; the repercussions on the other are examined if the situation involves interaction partners - and the consequences that result from the actions taken. In the present investigation, microgenetic analysis focused on behaviors that showed evidence of the empathic phenomenon.

The sessions were closely watched over and over in order to identify episodes with the potential to infer empathy in 2 and 3 year olds. This task was done individually by the researchers and, if in doubt, the session was watched and discussed with the entire research group to ensure that the identified clues could be taken as evidence of empathy. This, however, was not meant as a judging task by independent judges, but as an exercise of clarifying the phenomenon, ensuring the limits and possibilities of such inference. It is noteworthy that the beginning and end of each episode - the videotape clipping examined were delimited by flexible criteria based on the interactional flow: the beginning of an episode could correspond to the involvement of two or more children in a common activity, whether in play or not; the ending could correspond to the end of the session, the change in the theme of play, the intervention of an adult, etc. After delimitation, the episodes were carefully transcribed, noting verbal and nonverbal cues, movements and physiognomic expressions, spatial arrangements and configurations, etc.

Each transcribed episode was read several times, seeking to understand the aspects of the empathic phenomenon that each interaction allowed to discuss. In the next moment, it felt necessary to make a new, more summarized transcript without, however, missing details relevant to the analysis. We also sought the joint understanding of all of the transcribed material and the articulation of the different episodes.

\section{Ethical Considerations}

Consent was obtained from the Department of Education of the municipality, which was included in the protocol submitted to the Ethics Committee on Human Research. The Committee authorized the commencement of collection (CAAE 35013814.6.0000.5208). The researchers 
also obtained the consent of children's parents or guardians for their participation in the study, including authorization for video recording and use of images for the purpose of publishing research and adult professional training. The educators agreed with the investigation and provided moments of free situations for the observation of children. In the reporting, fictitious names were used, followed by the child's gender and age (months) in parentheses, separated by a slash.

\section{Results}

The episodes analyzed totaled approximately 41 minutes of cooperative play started and 38 minutes of interactions in which the playing did not take place. For the present article, we selected three episodes that describe the construction or attempt to construct collective play and its different consequences in order to illustrate the analysis undertaken, since presenting the whole qualitative analysis would go beyond the space available for a journal article. The three episodes chosen, therefore, represent the variety found in the set of video recordings: the first illustrates a coordinated cooperative play carried out by a group of children, but with the frustrated participation of one of them, who tried to prevent the continuity of the playful enterprise; the second episode describes a proposal by a boy to play with a partner who does not welcome his invitation; the third episode is also a co-operative coordinated play, which has a long storyline, made possible by the unfolding of children's actions and spatial arrangements in different parts of the room. In each of the episodes we will highlight the behaviors of one or more children who are interpreted by others as evidence of affective dispositions to play, with the potential to make the construction of scripts to be shared.

\section{Episode 1: Of the mats}

Children involved. Dário (M/33m), Levi $(\mathrm{M} / 31 \mathrm{~m})$, Marcilia (F/30m), Paulo (M/33m), Lis $(\mathrm{M} / 35 \mathrm{~m})$, Cadu $(\mathrm{M} / 35 \mathrm{~m})$, Hilton $(\mathrm{M} / 32 \mathrm{~m})$.

As the video recording starts, one can see that the children are placing mats on the living room floor next to each other, forming a large carpet. The camera focuses on Levi at the back of the room. Dario joins Levi, throwing himself with the mat on the floor. There are five children engaged in the game: Cadu, Lis, Paulo, Dário and Levi. The latter is covered with mats and the children are sitting around it. The atmosphere is very buzzing. Hilton, Dário and Paulo pull the mat. Levi gets up and clings to the mat trying to pull it to the floor again, demonstrating that he wants to continue that play. Dário holds Levi and falls over him. Paulo falls after Levi. The intern warns: "Yeah, Dário!" Levi holds the mat and a part covers his face. Paulo, sitting next to him, pushes the object away a little. Levi looks at Paulo. He repeats the movement in an effort to rid Levi's face of the mat. Hilton and Dário get up. Dário tries to pull Levi's mat, but Hilton throws himself on Levi. Paulo keeps watching Levi. Then, displaying apprehension, he turns to the intern and says, "Oh, come on, oh!" The intern responds in a complaining tone: "Hilton, it's hurting Levi." Hilton walks away. Paulo turns to Levi and tries to remove the mat that covers him. Dário then pulls the mat. Levi rolls over it. Hilton approaches again. Paulo shouts out loud. Levi looks at Paulo. Hilton and Dário wrap the end of the mat to cover Levi, who puts his right arm out of the mat and seems to enjoy that. Paulo gets up. Marcília helps Hilton and Dario to throw themselves on Levi, who is now covered by the mat. Paulo pushes Hilton. The intern approaches and says, "Get out of there, Levi!" Then she pulls him, holding him by the arm. Paulo watches as Levi comes out of the mat, then walks away and goes to push a classmate sitting in a cart. The other children resume the game. The intern no longer interferes.

The social dynamics established by the interactions of the partners entail the script of cooperative coordinated actions: it can be said that children play about throwing themselves on the mats, while at the same time being involved in them, as if they represented bed and sheet at once. They play happily: they exhibit laughter, sound and wide, agitated movements. Even so, Paulo expresses apprehension: noting that Levi has a part of his face covered by a mat, he pushes the object away. He does not seem to understand the sign of contentment of the children. Levi looks at him. Hilton and Dario get up and continue the play of pulling the mat or falling on Levi, which is covered by one of them. Paulo shows concern for Levi and calls the intern who complains about Hilton. Even so, Paulo moves the mat away again. Dário tries to continue the game by wrapping Levi in the mat, and Paulo shouts to try to prevent the boys from doing so - the scream is a display of discomfort. Levi looks at Paulo, but does not show suffering or seem to want to get out of the game. The intern approaches and takes Levi from under the mat, but the latter resumes the previous actions.

Based on this segment, we focus on a possible difficulty experienced by Paulo in assessing the affective disposition of his playmates and, specifically, the question is: is he empathic with Levi? At first Paulo engaged in the game, but from the moment he saw Levi's face covered, he assessed that he would be uncomfortable and tried to remove the mat; Paulo no longer shared the common theme of the group. Levi, in turn, showed no discomfort or solicited help. On the contrary, he indicated that he was engaged in the game: continued to pull the mat to cover and also allowed to be covered by the boys. It can be said that Paulo placed himself in the other's perspective, in Levi's perspective, but made a misjudgment about his partner's affective disposition: Paulo sought to protect him in various ways by making sure that Levi was not choking on the mat, but did not grasp the clues that informed him of Levi's satisfaction in sharing that game; he laughed and sought to continue his playmates' actions, including covering his own face. In addition, there were signs of great group fun, with laughter and vocalizations of contentment.

There are no other clues to understand the inadequacy of Paulo's assessment of the affective dispositions of his playmates, especially Levi's. Was it because of some traumatic experience Paulo experienced in another context 
or at another time? And if so, why did Paulo not correct his "mistake" during the various attempts he undertook in the episode examined? Levi was pleased with what was happening - but not just him - and even transgressed the adult's command to prevent the mat from covering his face.

It appears that Paulo's misreading prompted him to try to remove the mat from Levi's face, to complain about those who continued to play, to ask the intern for help to intervene and, in this sense, "hinder" the development of the playful enterprise. The difficulty experienced by Paulo was a hindrance to his engagement in the game, as well as to the development of the game itself. It seems that it is not enough to put oneself in the other's shoes; it is necessary to make correct assessments of the group's affective climate and, especially, the affective dispositions of the other/s.

But is the proper evaluation of the dispositions of the other a prerequisite for the effective fulfillment of a cooperative play enterprise? In the following episode it is possible to observe an interaction in which Iko uses different strategies to approach and engage in a game with Lia, though such an attempt is not effective.

\section{Episode 2: How do I approach?}

Children involved. Ivo (M/27m), Iko (M/27m), Lia (F/33m)

Lia, sitting on the floor, plays with plates and pans that are in a large container on her legs. Some other toys are around her. Only one child, Ivo, is sitting in front of her, facing her, but playing alone. Iko enters the scene, approaches Lia, bends down and picks up a plastic plate that is inside her container. Lia shouts, "No!" She takes the plate back. Iko comes over to her and pats her head and shoulder lightly - the movement of the hand resembles a few beats as you do when you want to call a person that is close. Lia looks at Iko and slaps him. Iko puts a thumb in his mouth and keeps looking straight at Lia. This one repeats the "no", slaps him again, which this time fails to reach him, and says something [incomprehensible], keeping the left arm raised in a threatening posture. Lowering his arm, Iko immediately removes his finger from his mouth. Lia goes back to manipulating the objects inside her container. Iko then picks up two farther plates and sits nearby. Lia watches him sideways. Iko says something to Lia [incomprehensible]. She looks at him, suspends the container she was playing with, and starts to move it out of Iko's reach. He calls him with a hand gesture. Lia spins her body, protecting her objects. Iko, sitting, crawls to approach her. Lia turns her body away from Iko, her back to him. Iko approaches, and she spins even more. The boy collects some plates scattered on the floor. Lia keeps playing with her objects. Iko makes a move to get up, but instead tries to pick up objects under the furniture. Lia gets up and walks away.

When trying to pick up an object from Lia, Iko "invades" her personal space, and this prompts her to respond immediately: the girl exhibits indignation/ annoyance - takes the object from Iko's hand, hits him and continues with her hand raised, as if she threatened him to avoid another attempt. Iko, with light patting on Lia's head and shoulder, seems to want to tell her something, or to give her a little cuddle, or even to want to establish a friendly approach with the girl. Lia, however, reacts negatively to this approach with a slap. Iko puts his thumb in his mouth, like a younger child's posture; Lia lowers her raised hand "ready for the attack"; Iko immediately removes his thumb from his mouth and turns around for available objects. This sequence of displays by Lia and Iko communicate their affective dispositions to each other. We could imagine a word dialogue corresponding to these displays: - "If you take my toys I am going tohit you." - "Don't hit me, I'm small." - "Okay, but don't take my toys!"

There are other attempts by Iko: a little farther away, he sits down and calls her with a hand gesture. Lia declines the invitation: she suspends the container that was resting on her legs and turns her body, turning her back to him. Iko, again, adjusts himself to approach her to sit beside her. Lia turns her body once again, as if to keep her toys out of the boy's reach; then she decides to get up and leave.

When Iko lightly pats Lia's head and shoulder, it seems to signal an attempt at reconciliation with her, as his first attempt had provoked a strong and negative reaction from the girl. However, Lia did not understand or acted accordingly. It was not clear to her if Iko's interest was to take her toy or play with her. Or, another plausible hypothesis, she realized that Iko wanted to play with her, but she lacked the motivation to share with him. When the boy sits next to her already in possession of two similar plates, his intention to play with her is more clearly set: having toys like hers - imitation of the use of objects -, he persists in approaching Lia.

The playful enterprise failed, as can be seen from the absence of display of satisfaction and sharing, such as exchange of smiles, synchronization of rhythm and turn taking. There are also Lia's displays of refusal: saying no, pulling the toy back, slapping his classmate, ignoring his call, and running away from a spatial approach. On the part of Iko, there are displays of wanting to play with her, such as: trying to pick up the objects being used in play, physically approaching her classmate, calling her, touching her body carefully after she had firmly recovered the object that had been taken from her, etc.

It is possible that Lia refused to play with Iko because of his initial approach or for other reasons that refer to previous experiences that go beyond the episode analyzed. Whatever the reasons, it is clear that despite Iko's various attempts, he and Lia failed to engage in play.

It is understood that the children were able to express clearly their affective dispositions, either of interest or disinterest in their partner and play. In this sense, it is possible to say that there is successful affective communication without the construction of play. This construction would refer to the existence of other aspects than just affective communication. 
From the episode "How do I approach?" It is possible to see that for partners to engage in play, it is necessary that they simultaneously want to play. The lack of motivation of one of the pair's children to engage in play would be directly related to the failure of the playful enterprise. In the episode, Lia's lack of motivation to play with Iko was one of the hypotheses raised, although the refusal may also have been due to retaliation for Iko's first attempt not having met the prerequisites of a good encounter.

The next episode is titled "Playing day care" and deals with the interaction of a subgroup of children who engage in play. The analysis of this episode allows us to raise behaviors that indicate how the play was built and developed.

\section{Episode 3: Playing daycare}

Children involved. Hilton (M/33m), Mily ( $\mathrm{F} / 39 \mathrm{~m})$, Iko (M/27m), Ivo (M 27m), Luna (F/33m), Dário (M/34m), Miguel $(M / 34 m)$, Cadu $(M / 36 m)$, Paulo $(M / 35 m)$, Vily $(\mathrm{M} / 31 \mathrm{~m})$, Nanda $(\mathrm{F} / 38 \mathrm{~m})$.

At the beginning of the session, we see Hilton, Mily, Iko and Luna walking in the room, holding hands. Ivo and Dario join the group and hold hands with their partners. Some children move away, but Luna, Ivo, Dário, and Vily hold hands, standing in the corner of the room. Iko returns to the group. The children stand in a semicircle and shake their heads from side to side. Mily approaches the group imitating this movement; shortly thereafter the children stop shaking their heads. Hilton holds the hands of Mily and Iko; Mily takes Vily's hand and everyone closes the circle. The children play spinning and spinning, and while Luna sings "I threw the dick at the cat," they all follow the music making sounds and shaking their heads. Luna shouts "Meow" and drops to the floor. The children make the same move and also shout "Meow!" Luna gets up and says, "Let's do it again!" She reaches out to the partners beside her. The children get up and hold their hands again but no longer form the circle. They talk to each other, laugh and move around; release their partner's hand for an object, but return to the small group; other children come and go; there is imitation of gestures of each other; they persist in walking around the room holding hands... Luna, Iko, Hilton, Mily, Miguel and Dario are sitting on the floor in a circle. Luna tells Iko to lean against the chairs behind him, and also tells the group: "Come over here, come over here!" She sits next to Iko and claps her hand on the floor as if to call someone to sit by her side. Dário creeps to be beside Luna. Nanda joins the group and upon arriving pulls Dário back as if adjusting his position. Luna aligns and sits next to Dário in the position that Nanda placed him. Luna talks to Nanda and points to Miguel. Nanda pulls Miguel, adjusting his position to the group. Then does the same with Mily, Hilton and Iko. The children allow to be pulled and Mily and Miguel look at Nanda and smile. Nanda pulls Dário farther back. Luna moves to sit next to Dário. Ivo comes to the group and sits near Dário' feet. Nanda pulls him to sit beside him and Ivo lets himself be pulled. Vily approaches and tries to pull Dário as if imitating Nanda. The children begin to sing a song and make gestures like a choreography that everyone knows. The scene is reminiscent of the organization that the teacher or the Child Development Assistants (ADIs) do to start an activity with the children sitting on the floor ... . Nanda is still standing, organizing the children. Iko leaves the place Nanda had put him and she pulls him to the place of origin; she sits next to him. The children begin to sing the song with which they start their daily routine: "Good morning, little pal". Iko gets up and pulls Mily, mimicking Nanda's movement. She gets up and pulls Mily and sets other children in the group. Cadu joins the group and turns to Hilton, the one holding a ball; he prepares to play. Nanda tries to match him to the arrangement and he whimpers. Nanda then tries to pull Hilton, unsuccessfully. Several children begin to do activities with their close partners, even though they remain in the spatial arrangement, which is gradually falling apart with the children's continuous movements.

The behavior of walking hand in hand at the beginning of the episode catches the attention of other partners who join the group and accompany them around the room. They form a semicircle, shake their heads and show contentment. Mily watches the group and tries to include herself in the game. To this end, Mily mimics her peers' behavior and comes closer, shaking her head and arms to hold the hands of other children. Getting into the group by imitating what the children are already doing is a successful strategy; Ivo and Dário also use it to get closer to the group.

Luna starts singing "I threw the stick at the cat" and the children start spinning, playing a circle game. Some children still shake their heads. Luna shouts "Meow", bends down, and the group imitates her. There is an effort by the group to maintain that arrangement, even though it may occasionally be reconfigured for the sake of meeting specific interests, such as picking up an object, accommodating an incoming partner, walking hand in hand in tight spaces with hurdles on the floor, etc.

When they reach the center of the room, Nanda joins the game by continuing Luna's indications, and acts to better arrange the group in preparation for a routine activity, which teacher and ADIs perform in the daily life of the day care center. She pulls the children and rearranges those who engage in the "Good Morning" circle activity - the name of the activity where children talk to the teacher and sing the songs the teacher sings. Luna continues guiding the play, singing and gesturing children's everyday songs. The other children also do their part by adjusting to the care of the "teacher" and the "helpers". The children's behavioral displays inform the theme that is shared (of what is played), promote the recognition of the characters that entangle the playful situation and indicate the affective mood of the situation. 


\section{Discussion}

The present study aimed to understand the construction of cooperative play through empathy in 2-3 year olds. Considered a multidimensional construct with affective, cognitive and social components, the empathic phenomenon was inferred through behaviors that denote satisfaction, partner acceptance, threat, dispute, reconciliation, comfort, among others, emphasizing its communicative role in interpersonal relationships. The episodes showed that even in these early years of life, children attribute meaning to behaviors exhibited by partners and are able to adopt their perspective cognitively and affectionately, as well as being able to be sensitive to them, caring for their well-being. In turn, these partners also perform actions and gestures that gradually harmonize with theirs, expressing mutual understanding and concern. This interactional play reveals selection, experimentation, and choices of what to do and how to do it. Together they build adjustable interactional sequences that repeat but also renew themselves, correcting pathways and appropriating actions and reactions that seem to have worked.

In any interactional situation, empathy is a relevant psychological phenomenon and, therefore, it is also relevant to a collective playful endeavor, especially when children have not yet mastered verbal language. It reveals itself as an affective communication medium, through which the child proposes, accepts, rejects and negotiates scripts, plots, objects, roles and positions in play. All this organizes and incites new actions and meanings in continuous unfolding, resulting, among other things, from the recognition and acceptance of the affective dispositions of the interactants. Therefore, empathic communication plays a functional role in peer interactions: it encourages the sharing of intentionality - an essential process for the constructionanddevelopmentofcollectiveplay(Tomasello\& Gonzalez-Cabrera, 2017).

The results also provide evidence that the construction of a cooperative play is related to the presence of successful affective communication. The mats episode revealed that a child, Paulo, by improperly attributing significance to the affective disposition of a partner - possibly fear of asphyxiation as a result of a mat that covered his face tried to prevent the play from continuing, even with the displays of contentment by the partner and other children who shared with him. There was evidence that Paulo put himself in the other's perspective and worried about his well-being; however, for unknown reasons, his assessment of the partner's affective dispositions was inadequate, but this does not warrant saying that the cognitive component of empathy was absent. After all, there was an assessment of a risk to the classmate's well-being. Some event that occurred outside the range of observation may have obscured the recognition of the partner's affective clues of joy and contentment. Therefore, we point out the need to deepen this issue.
Another point to be emphasized from the results is that successful affective communication, one in which one's behavior is properly interpreted, does not guarantee a shared playful endeavor; the motivation to play with the partner is a relevant aspect to consider. In episode $2-$ "How do I approach?" - many attempts were made by Iko, conspicuously demonstrating that he wanted to play with Lia. She evidenced that she "read" Iko's attempts correctly, but also displayed signs that indicated her refusal. When approaching Lia, Iko took a toy from the girl without obeying the prerequisite of a friendly approach, i.e., Iko "invaded" Lia's personal space, reaching an object that was in her container. Lia's reaction was immediate: she hit Iko and maintained a threatening stance for a while. Attributing proper meaning to a partner's affective dispositions, understanding his/her perspective, does not ensure that one wants to approach him/her or want to accomplish something with him/her; being sensitive to the well-being of others is in keeping with one's own well-being. It is necessary to discuss the relationship between empathy and altruism and the limits and scope of that relationship. Some conditions must be respected (Pessôa et al., 2015).

In the episode "Playing daycare", it is understood that Luna plays the role of teacher and therefore guides the songs and the group; Nanda appears to be an ADI whose role is to organize the children to sit next to her and Luna. The group behaves like children attending daycare and are organized into daily activities. Each of these roles has demarcated displays and dispositions, and the process of joining in play relates to the ability to understand each other's role, recognize these behaviors and adjust to them. Imitation is the main resource they use, both to inform their partner of their affective dispositions in play and, conversely, to signal recognition of what they do, what they want and what they appreciate; this also provides for the establishment of coordinated action and allows the emergence of a meaning for play (Bussab et al., 2007; Viana \& Pedrosa, 2014; Wallon, 1949/1986).

This episode reveals the existence of a unique topic, "playing daycare", which articulates the experience of different characters with their roles that complement and specify each other, entangling interactive exchanges and allowing the implementation of cooperative actions. Satisfaction displays tell partners how enjoyable the activity is, and by orienting and joining in the activity, children capture conspicuous clues about how to play, allowing the sharing of constructed meaning (Tomasello \& GonzalezCabrera, 2017). This common topic is here theoretically identified as an attractor (Lucena \& Pedrosa, 2014), because it condenses a set of meanings, allowing to eliminate actions not pertinent at that time, and electing other actions as appropriate, even though these sometimes need adjustments or additions. It is understood that shared meaning has the potential to persist and evoke similar episodes at other times of group interaction. 
The present study points to the need for further research that may continue to investigate the role that the empathic phenomenon plays in the construction and development of children's cooperative play. We suggest further investigations in different age groups, using methodological procedures that can complement the observational findings reported here, for example, observing various situations and performing analyses with independent judges.

Detailed behavioral descriptions may prompt research in the field of neuroscience with questions about the neuropsychological correlates of such behaviors. These findings may also contribute directly to practices in the field of early childhood education, contributing to the construction of knowledge about early peer interactions and the process of human development.

\section{References}

Bischof-Köhler, D. (2012). Empathy and self-recognition in phylogenetic and ontogenetic perspective. Emotion Review, 4(1), 40-48. doi:10.1177/1754073911421377

Bischof-Köhler, D. (2013). Erratum: "Empathy and self-recognition in phylogenetic and ontogenetic perspective". Emotion Review, 5(1), 116. doi:10.1177/1754073912471619

Bussab, V. S. R., Pedrosa, M. I., \& Carvalho, A. M. A. (2007). Encontros com o outro: Empatia e intersubjetividade no primeiro ano de vida [Encounters: Empathy and intersubjectivity in the first year of life]. Psicologia USP, 18(2), 99-133. Retrieved from http://pepsic.bvsalud.org/scielo.php? script $=$ sci_ $_{-}$ arttext\&pid=S1678-51772007000200007

Costa, C. A., \& Amorim, K. S. (2015). Abreviação em relações de bebês com seus pares de idade [Abbreviation within peer infant's relations]. Psicologia: Teoria e Pesquisa, 31(1), 15-23. doi:10.1590/0102-37722015011798015023

de Waal, F. B. M., \& Preston, S. D. (2017). Mammalian empathy: Behavioural manifestations and neural baes. Nature Reviews: Neuroscience, 18(8), 498-509. doi:10.1038/nrm.2017.72

Del Prette, Z. A. P., \& Del Prette, A. (2013). Psicologia das habilidades sociais na infância: Teoria e prática [Psychology of social skills in childhood: Theory and practice]. Petrópolis, RJ: Vozes.

Gallese, V. (2013). Mirror neurons, embodied simulation and a second-person approach to mindreading. Cortex, 49(10), 2954-2956. doi:10.1016/j.cortex.2013.09.008

Gallese, V., \& Ebisch, S. (2013). Embodied simulation and touch: The sense of touch in social cognition. Phenomenology and Mind, (4), 196-210. doi:10.13128/ Phe_Mi-19602
Gómez, M. C. (2016). Empathy in early childhood. Psicodebate, 16(2), 35-50. doi:10.18682/pd.v16i2.593

Lucena, J. M. F., \& Pedrosa, M. I. (2014). Estabilidade e transformação na construção de rotinas compartilhadas no grupo de brinquedo [Stability and change in the construction of shared routines in playgroups]. Psicologia: Reflexão e Crítica, 27(3), 556-563. doi:10.1590/16787153.201427317

Menezes, S., \& Bichara, I. D. (2016). Observação de situações do cotidiano: Brincadeiras espontâneas na escola [Observation of everyday situations: Spontaneous plays at school]. Revista Brasileira de Psicologia, 3(1), 77-89.

Pinho, V. D. D., Falcone, E. M. O., \& Sardinha, A. (2016). O papel preditivo da habilidade empática sobre o perdão interpessoal [The predictive role of empathic skill on interpersonal forgiveness]. Temas em Psicologia, 24(4), 1507-1518. doi:10.9788/TP2016.4-17

Pessôa, L. F., Seidl-de-Moura, M. L., Mendes, D. M. L. F., Carvalho, R. V. C., \& Stobaus, L. C. (2015). Cooperação e altruísmo no segundo ano de vida e crenças e práticas maternas: Um estudo exploratório [Cooperation and altruism in the second year and maternal beliefs: An exploratory study]. Psico, 46(2), 217-225. doi:10.15448/1980-8623.2015.2.17368

Piaget, J., \& Inhelder, B. (1980). A psicologia da criança [The psychology of the child] (O. M. Cajado, Trans.). São Paulo: Difel. (Original work published in 1966).

Plutchik, R. (1990). Evolutionary bases of empathy. In N. Eisenberg \& J. Strayer (Eds.), Empathy and its development (pp. 38-46). New York, NY: Cambridge University Press.

Roth-Hanania, R., Davidov, M., \& Zahn-Waxler, C. (2011). Empathy development from 8 to 16 months: Early signs of concern for others. Infant Behavior \& Development, 34(3), 447-458. doi:10.1016/j.infbeh.2011.04.007

Saullo, R. F. M., Rossetti-Ferreira, M. C., \& Amorim, K. S. (2013). Cuidando ou tomando cuidado? Agressividade, mediação e constituição do sujeito: Um estudo de caso sobre um bebê mordedor em creche [Caring or being careful? Aggressiveness, mediation and constitution of the subject: A case study of a biting baby in a daycare center]. Pro-Posições, 24(3), 81-98. doi:10.1590/S010373072013000300006

Tomasello, M., \& Gonzalez-Cabrera, I. (2017). The role of ontogeny in the evolution of human cooperation. Human Nature, 28(3), 274-288. doi:10.1007/s12110-017-9291-1

Viana, K. M. P., \& Pedrosa, M. I. (2014). Brincadeiras coordenadas cooperativas e o compartilhamento de intenções em crianças [Cooperative coordinated play and sharing intentions among children]. Psicologia: Reflexão e Crítica, 27(3), 564-572. doi:10.1590/1678-7153.201427318 
Wallon, H. (1986). Sincretismo diferenciado: A simpatia. [Differentiated syncretism: Sympathy]. In M. J. G. Werebe \& J. Nadel-Brulfert (Orgs.), Henri Wallon (pp. 38-49). São Paulo, SP: Ática. (Original work published in 1949).

Paula Gabrielly Rasia Lira is a Psychologist, Master at the Universidade Federal de Pernambuco, Recife-PE, Brazil.

Maria Isabel Pedrosa is a Professor of Psychology of the Universidade Federal de Pernambuco, Recife-PE, Brazil.

\section{Authors' Contribution:}

Both authors made substantial contributions to the conception and design of this study, to data analysis and interpretation, and to the revision and approval of the final version of the manuscript. Both authors assume public responsibility for the content of the manuscript.

Received: Oct. 09, 2017

1st Revision: Mar. 29, 2018

2nd Revision: Aug. 07, 2018

3rd Revision: Aug. 24, 2018

Approved: Sep. 21, 2018

How to cite this article:

Lira, P. G. R., \& Pedrosa, M. I. (2019). Empathic communication on cooperative play in children of 2 and 3 year olds. Paidéia (Ribeirão Preto), 29, e2939. doi:http://dx.doi.org/10.1590/1982-4327e2939 